\title{
Allelopathic Effects Produced by Johnson Grass Extracts over Germination and Growth of Crop Plants
}

\author{
Ramona ȘTEF ${ }^{1 *}$, Alin CĂRĂBET ${ }^{1}$, Ioana GROZEA ${ }^{1}$, Isidora RADULOV ${ }^{1}$, Dan MANEA ${ }^{1}$ and Adina \\ BERBECEA $^{1}$ \\ ${ }^{1)}$ Faculty of Agriculture, ${ }^{1}$ Department of Biology and Plant Protection, Banat's University of \\ Agricultural Sciences and Veterinary Medicine "Regele Mihai I al României" from Timisoara, Calea \\ Aradului 119. Timisoara. 300645 \\ * corresponding author: chirita_ramona@yahoo.com
}

Bulletin USAMV series Agriculture 72(1)/2015

Print ISSN 1843-5246; Electronic ISSN 1843-5386

DOI 10.15835/buasvmcn-agr: 11180

\begin{abstract}
The paper addresses a topic justified by economic importance due to direct and indirect damages caused by Johnson grass in maize and soy culture. The study aimed to highlight the allelopathic effects produced by Johnson grass extracts on seed germination, plant height and plant dry mass of corn and soybeans. The research was conducted in the laboratories of Agrochemistry and Plant Protection Department in University of Agricultural Sciences and Veterinary Medicine of Banat. Experimental field has 13 variants, which are different throughout plant material used (rhizomes dry, fresh, leaves, and seeds) as well as various alcohol concentrations. Following the treatments application with extracts we observed that the highest allelopathic effect is determined by extracts based on rhizome, second being situated leaf extract. The aqueous extracts were less inhibitory compared with the alcoholic extracts. Lowest content of alkaloids that cause allelopathic effect is recorded in seeds. The experiment showed that the seed germination percentage of inhibition depended on the time used and the concentrations of the plant material used (rhizomes, leaves, seeds).
\end{abstract}

Keywords: allelopathic extract, germination, Johnson grass, maize, soy

\section{INTRODUCTION}

Corn occupies third place as importance among cultivated plants worldwide (Muntean et al., 2003). Glycine max L. Merrill. (soybean) is one of the most important leguminous in the world, due to the high nutritional value of the kernel and high protein content (38-42\%) (Nguyen et. al., 2010). These crops (corn and soybeans) compete with many pathogens, pests and weeds, but the highest loss of production is determined by weeds, especially the species Sorghum halepense L. This species is a very competitive and invasive weed, is the most damaging weed in Romania hoeing crops, to the competitive capacity of Johnson grass add allopath producing substances that negatively influence the germination of other plant species. Allelopathic effect of this species is determined by the cyanogenic, glycogenic and phenolic compounds contributing to the suppression of growth of crop plants (Ștef et. al., 2013).

"Biochemical inhibition" theory of de Candolle (1832) was confirmed in 1937 by Molisch, who introduced the term scientific of "allelopaty”, referring to the "biochemical dialogue" between organisms (Cristea et al., 2004). The word "allelopathy" is derived from two separate words. These are allelon meaning "one another", and pathos meaning "to suffer". Allelopathy refers to the inhibition of a chemical species to another. "Inhibitory" substances are released into the 
environment where it affects the development and growth of surrounding plants (Ferguson et al, 2013). This antagonistic phenomenon is a form of competition between weeds and plants. This biochemical interaction consists of the removal of root exudates, foliar and stem. Active secretions are produced by live organs of the plant, and the passive, come from the dead organs in the course of decomposition (Chirilă, 2001). Although biochemical process has been studied by many phytosociologs: Grümmer (1955), Rademacher (1959), Kursanov (1966), Müller (1969), Rabotnov (1974), Chircă and Fabian (1985) the inner mechanism of allelopathy has not yet been elucidated (Cristea et al., 2004). Allelopathy is a naturally occurring phenomenon which refers to any direct or indirect effect, positive or negative of a plant of the other by the release of chemical compounds into the environment (Delabays et al. 2004).

The structure and mode of action allelopathic substances are different, due to this fact can be used for future development of herbicides (Uludag et al., 2005; Weston, 2005).

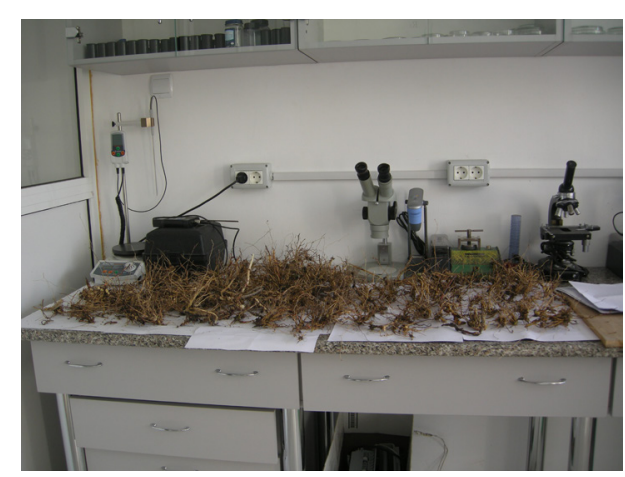

a. Samples preparing

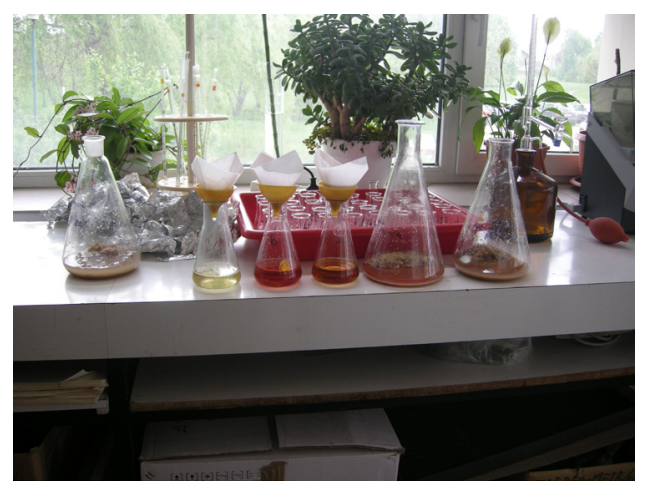

c. Solution filtering
In this work were studied under laboratory conditions, the effects of aqueous and alcoholic extracts of Sorghum halepense L. on germination and growth of corn and soybean plants.

\section{MATERIAL AND METHODS}

The researches were conducted in the laboratories of Agrochemistry and Plant Protection Department in University of Agricultural Sciences and Veterinary Medicine of Banat from Timisoara.

As the first steps of the research were harvested Johnson grass mature plants, exactly in 30.09.2013. The aerial organs of samples were separated.

Preparation of the extracts from dried rhizomes was done in the following way: the roots were washed, dried (for 14 days at a constant temperature of $26.6^{\circ} \mathrm{C}$ ) and finally, shredded (included in the extract of rhizomes and adventitious roots).

For the fresh rhizome, leaves and seed extracts was made harvesting and shredded. Each extract was composed of $4 \mathrm{~g}$ of dried or fresh material that added water and ethyl alcohol concentration

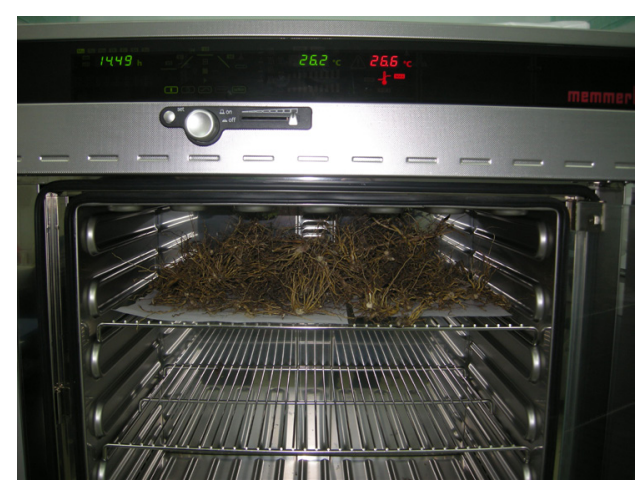

b. Roots drying for extracts

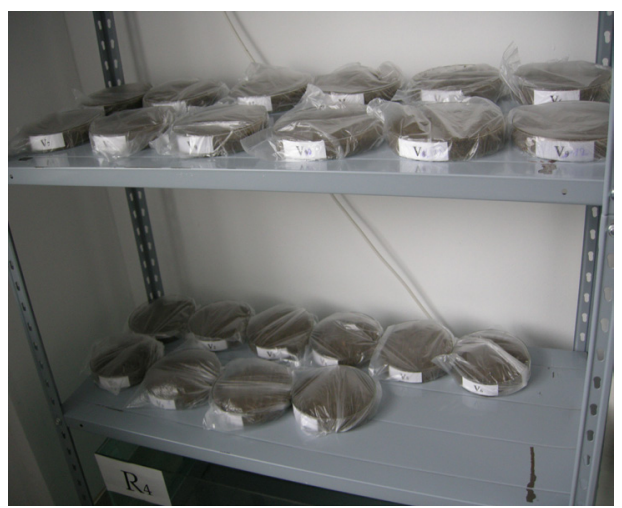

d. Installing experimental variants

Fig. 1. Aspects during experience placement 
$98 \%$, they were placed in horizontal and magnetic stirrer for 24 hours, followed by filtration. All the extracts were filtered and stored in a glass bottle at $4^{\circ} \mathrm{C}$. The experiment included 13 variants:

$\mathrm{V} 1$ = control = distilled water;

$\mathrm{V} 2=10 \%$ alcohol + dried rhizomes;

$\mathrm{V} 3=20 \%$ alcohol + dried rhizomes;

$\mathrm{V} 4$ = distilled water + dried rhizomes;

V5 $=10 \%$ alcohol + fresh rhizomes;

V6 $=20 \%$ alcohol + fresh rhizomes;

$\mathrm{V} 7=$ distilled water + fresh rhizomes;

V8 $=10 \%$ alcohol + leaves;

V9 $=20 \%$ alcohol + leaves;

$\mathrm{V} 10=$ distilled water + leaves;

V11 $=10 \%$ alcohol + seeds;

$\mathrm{V} 12=20 \%$ alcohol + seeds;

V13 = distilled water + seeds;

Corn seeds were placed on a layer of filter paper in a Petri dish (10 seeds/petri dish) and covered with sterile sand each variant was wetted with $100 \mathrm{ml}$ of the extract.

The Petri dishes were placed in the laboratory at 12 hours light and $27 \pm 2{ }^{\circ} \mathrm{C}$ for 16 days. In the first three days the vessels were placed in bags. At the end of the incubation period the germination of corn seeds, the total fresh/dry weight and the plant height was determined.

The experiments were arranged in a completely randomized 3 repetitions for each treatment.

The total mass of dry material was determined by weighing with analytical balance. The data were statistically analyzed.

\section{RESULTS AND DISCUSSIONS}

Weeds cause substantial decline in agricultural production through direct and indirect effects. Indirect damages resulting from Johnson grass extracts on germination of corn and soybean plants are shown in tab. 1.

Following researches it was observed that 3 DAT (days after treatment) soybeans germinated in control variant treated with distilled water, while the other variants, treated with Johnson grass extracts was delayed 1-5 days. The data presented in Table 1 shows that the highest percentage of inhibition of germination was recorded in the variant treated with extract based on dried rhizomes at a concentration of $20 \%$, soybean seed germination was only $10 \%$. Soybean germination decreased in variants where in leaves extract was applied being placed, as allelopathic inhibition efficiency second compared with extract based on rhizomes. The highest percentage of seed germination of soybean $(90.0 \%)$ was recorded in the variant treated with seeds aqueous extract at a concentration of $20 \%$, it did not produce differences compared to the control. Maize seed germination following application of Johnson grass extracts in experimental variants had percentages ranging from 33.33 to $90.00 \%$.

Analyzing the data we see that the highest percentage of inhibition of germination was recorded in the variant treated with alcoholic extract of dried rhizomes at a concentration of $20 \%$ corn seed germination being just 33.33\%. Maize seed germination was reduced very significantly in the variants treated with Johnson

Tab 1. Effects on germination Johnson grass extracts (\%) of seed corn and soybeans

\begin{tabular}{|c|c|c|c|c|c|}
\hline \multirow[b]{2}{*}{ Crop } & \multirow[b]{2}{*}{ Plant organ } & \multicolumn{4}{|c|}{ Concentration } \\
\hline & & Control & $\begin{array}{c}\text { Aqueous } \\
\text { extract }\end{array}$ & $10 \%$ & $20 \%$ \\
\hline \multirow{5}{*}{ Corn } & Dried rhizomes & \multirow{4}{*}{96.66} & $60^{000}$ & $66.66^{00}$ & $33.33^{000}$ \\
\hline & Fresh rhizomes & & $76.33^{0}$ & $66.66^{00}$ & $46.66^{000}$ \\
\hline & Leaves & & 80.0 & $70.0^{00}$ & $53.33^{000}$ \\
\hline & Seeds & & 90.0 & 83.33 & $60.0^{000}$ \\
\hline & \multicolumn{2}{|c|}{ DL5 \%=17.68 } & DL $1 \%=24.02$ & DL $0.1 \%=$ & \\
\hline \multirow{5}{*}{ Soy } & Dried rhizomes & \multirow{4}{*}{96.66} & $66.66^{000}$ & $26.66^{000}$ & $10.0^{000}$ \\
\hline & Fresh rhizomes & & $76.66^{00}$ & $56.66^{000}$ & $36.66^{000}$ \\
\hline & Leaves & & $80.0^{0}$ & $76.66^{00}$ & $70.0^{000}$ \\
\hline & Seeds & & 90.0 & $80.0^{0}$ & $73.33^{000}$ \\
\hline & \multicolumn{2}{|c|}{ DL $5 \%=12,46$} & DL $1 \%=16.94$ & DL $0.1=0$ & \\
\hline
\end{tabular}


grass rhizomes alcoholic extracts applied at 20\% concentration.

Maize seed germination decreased in variants where the aqueous and alcoholic leaves extracts were applied being placed second as inhibition degree.

The highest percentage of germination of maize grains (90.00\%) was recorded in the variant treated with seeds aqueous extract, it did not produce differences from the control (photo 2).

Soybean seeds exhibited a much lower percentage of germination as compared to corn as a result of the extracts of the built it. Soufan et al., 2009 studied the allelopathic effect of Convulvulus arvensis L., Cyperus rotundus L. and Sorghum halepense L. on seed germination of corn, concluding that Johnson grass extracts show a greater inhibitory effect.

The highest inhibition of maize germination, fresh weight and shoot length were caused by rhizomes extracts of Johnson grass that are correlated with the results reported by Friedman and Horowitz (1971), who found that Johnson grass rhizomes extract caused higher inhibition of barley roots growth.

In the second part of the experiment was observed the allelopathic effect of Johnson grass extracts on maize and soybean plant growth (tab. $2)$. For this study, biometrical measurements were performed 16 days after treatments.

Through the application of alcoholic and aqueous extracts of fresh and dried roots, leaves and seeds of Johnson grass, has achieved a reduction of character "plant height" $(9.61 \mathrm{~cm})$ very significantly from the values obtained from untreated variant $(27.37 \mathrm{~cm})$.

Maize plants exhibited an average height of $16.85 \mathrm{~cm}$ and a minimum of $9.61 \mathrm{~cm}$, in the variant where the dry root extract was applied in a concentration of $20 \%$ and the maximum value $(24.87 \mathrm{~cm})$ recorded in variant where has been applied aqueous extract of seeds.

Highest allelopathic potential on growth inhibition of maize plants was recorded in variant where extracts of fresh and dry rhizomes of Johnson grass was applied, this result is explained
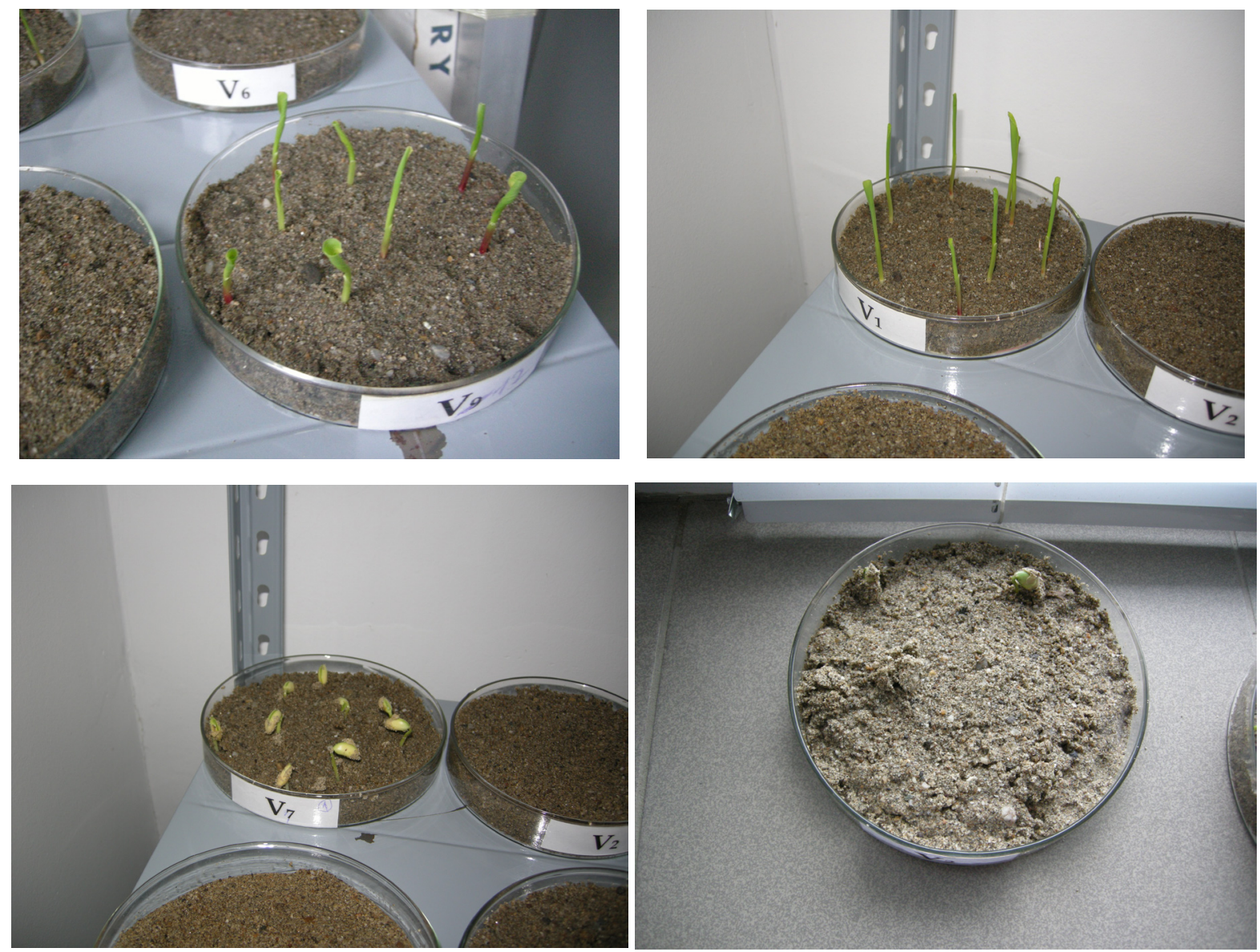

Photo 2. Aspects of experimental variations in different stages 
by Czarnota et al. (2001) which states that the roots of Sorghum halepense contain sorgoleone, a mixture of hydrophobic biologically active substances. Studies conducted by Sene et al., 2001 showed that Sorghum halepense produces and releases alkaloids that may contribute to the suppression of plant growth.

In terms of height maize plants, in treated variant with aqueous extract from Johnson grass seeds, was observed that recording value not shown significant differences, after statistical analysis.

Soybean plant growth was very negatively significantly influenced following the application of Johnson grass extracts. The height of the soybean plants in the experimental variants presented values between $5.31 \mathrm{~cm}$ and $18.22 \mathrm{~cm}$ and an average of $11.98 \mathrm{~cm}$.
In the variants that were treated with Johnson grass seed extracts, plant height presented significant differences $(18.22 \mathrm{~cm})$ and significantly distinct $(17.76 \mathrm{~cm})$ from the negative control treated with distilled water $(19.76 \mathrm{~cm})$.

After determining the dry weight (the analytical weighing balance) of the both crop plants used in the experiment it was observed that the soybean plants was strongly inhibited compared to the corn, the highest reduction of the dry mass is recorded in the variants in which rhizomes extracts were applied (tab. 3), second being placed levees extracts. The result is similar to that found by other researchers (Chun et al., 1998) who worked with allelopathic cultivars of rice.

Johnson grass seeds contain the lowest quantities of allelopathic substances.

Tab 2. Effects of Johnson grass extracts on plant height $(\mathrm{cm})$ of maize and soybean

\begin{tabular}{|c|c|c|c|c|c|}
\hline \multirow[b]{2}{*}{ Crop } & \multirow[b]{2}{*}{ Plant organ } & \multicolumn{4}{|c|}{ Concentration } \\
\hline & & Control & $\begin{array}{l}\text { Aqueous } \\
\text { extract }\end{array}$ & $10 \%$ & $20 \%$ \\
\hline \multirow{5}{*}{ Corn } & Dried rhizomes & \multirow{4}{*}{27.37} & $13.73^{000}$ & $12.33^{000}$ & $9.61^{000}$ \\
\hline & Fresh rhizomes & & $14.57^{000}$ & $16.61^{000}$ & $11.62^{000}$ \\
\hline & Leaves & & $22.30^{000}$ & $19.67^{000}$ & $17.33^{000}$ \\
\hline & Seeds & & 24.87 & $21.60^{000}$ & $17.93^{000}$ \\
\hline & \multicolumn{2}{|c|}{ DL $5 \%=2.51$} & DL $1 \%=3.40$ & DL $0.1 \%=$ & \\
\hline \multirow{5}{*}{ Soy } & Dried rhizomes & \multirow{4}{*}{19.76} & $9.58^{000}$ & $7.55^{000}$ & $5.31^{000}$ \\
\hline & Fresh rhizomes & & $12.86^{000}$ & $10.58^{000}$ & $9.0^{000}$ \\
\hline & Leaves & & $12.46^{000}$ & $13.56^{000}$ & $11.35^{000}$ \\
\hline & Seeds & & $18.22^{0}$ & $17.76^{00}$ & $15.56^{000}$ \\
\hline & \multicolumn{2}{|c|}{$\mathrm{DL} .5 \%=1.19$} & DL $1 \%=1.62$ & $\mathrm{DL} 0.1 \%=$ & \\
\hline
\end{tabular}

Tab 3. Influence of Johnson grass extracts on dry weight (g) of soybean and maize plants

\begin{tabular}{|c|c|c|c|c|c|}
\hline \multirow[b]{2}{*}{ Crop } & \multirow[b]{2}{*}{ Plant organ } & \multicolumn{4}{|c|}{ Concentration } \\
\hline & & Control & $\begin{array}{c}\text { Aqueous } \\
\text { extract }\end{array}$ & $10 \%$ & $20 \%$ \\
\hline \multirow{5}{*}{ Corn } & Dried rhizomes & \multirow{4}{*}{7.79} & $2.48^{000}$ & $1.73^{000}$ & $4.08^{000}$ \\
\hline & Fresh rhizomes & & $4.61^{000}$ & $5.45^{000}$ & $3.80^{000}$ \\
\hline & Leaves & & $6.71^{0}$ & $5.98^{000}$ & $6.13^{000}$ \\
\hline & Seeds & & 7.26 & $6.74^{0}$ & $6.32^{00}$ \\
\hline & \multicolumn{2}{|c|}{ DL5 $\%=0.81$} & DL $1 \%=1.11$ & DL $0.1 \%=1.48$ & \\
\hline \multirow{5}{*}{ Soy } & Dried rhizomes & \multirow{5}{*}{6.73} & $1.97^{000}$ & $1.74^{000}$ & $1.59^{000}$ \\
\hline & Fresh rhizomes & & $2.33^{000}$ & $2.53^{000}$ & $2.03^{000}$ \\
\hline & Leaves & & $4.60^{00}$ & $4.30^{000}$ & $3.90^{000}$ \\
\hline & Seeds & & 6.20 & 5.98 & $5.40^{0}$ \\
\hline & DL $5 \%=0.81$ & & DL $1 \%=1.45$ & DL $0.1 \%=2.34$ & \\
\hline
\end{tabular}


Dry mass of corn ranged between $1.73 \mathrm{~g}-7.26$ in the variants treated with extracts Johnson grass and a maximum of $7.79 \mathrm{~g}$ in the control variant. The results regarding dry mass of maize presented significant negative differences in variants treated with extracts of dried and fresh roots. Application of Johnson grass alcoholic extracts of leaves has determined very significant negative weights. Negative significant differences were recorded in the variants treated with seed extract at a concentration of $10 \%$ and aqueous extract of leaves. In the variant treated with aqueous extract from the seeds of the dry mass of maize plants had an average value of $7.26 \mathrm{~g}$, did not produce statistically significant differences.

After determining the dry weight of the soybean plants of the variants treated with seeds alcoholic and aqueous extracts, at 10\% concentration showed no differences compared to the control, at a concentration of $20 \%$ was achieved a significantly lower plant weight compared to plants treated with distilled water $(6.73 \mathrm{~g})$.

The extracts of the leaves and fresh and dry root determined a very significant decrease of the dry mass of the soybean plants.

The results of this study are in agreement with those registered by Beckett et al. (1988) and Yang (2004), they showed that germination, shoot lenght and dry weight of maize were significantly affected by the type of extract, its concentration and the species to which it belongs.

The study revealed that plants maize and soybeans were strongly influenced by the application extracts from rhizomes of Johnson grass, which leads us to say that the largest amount of sorgoleone is found in the roots, the second hovering leaf extracts.

The results demonstrate the alelopat potential of Johnson grass, this property may explain the character of invasiveness of the species and the growing presence in agro-ecosystems and ecosystems.

\section{CONCLUSION}

The experiments results obtained in laboratory have indicated the presence of inhibitory substances in all Johnson grass plant organs studied (roots, leaves, seeds).

Extracts from the roots of Johnson grass reduced significantly the germination, plant height and dry mass of corn and soybeans.
Following the study carried it was found that soybean plants are more affected by the Johnson grass extract compared to corn plants

\section{REFERENCES}

1. Beckett TH, Stoller EW, Wax LM (1988). Interference of four annual weeds in corn (Zea mays).Weed Sci. 36:764769.

2. Chirilă C (2001). Biologia buruienilor. Editura Ceres București. 56-59

3. Chou CH, Lin HJ (1976). Autointoxication mechanism of Oryza sativ I. Phytotoxic effects of decomposing rice residues in soil. J. Chem. Ecol. 2:353-367.

4. Chou CH (1998). Adaptive autointoxication mechanisms in rice. Allelopathy in rice. Edited by M. Olofsdotter. Manila. Philippines

5. Chun MM, Golomb J D, Turk-Browne NB (2011). A taxonomy of external and internal attention. Annu. Rev. Psychol. 62:73-101

6. Cristea V, Gafta D, Pedrotti F (2004). Fitosociologie. Editura Presa Universitară Clujeană

7. Czarnota MA, Paul RN, Dayan FE, Nimbal CI, Weston LA (2001). Mode of action, localization of production, chemical nature, andactivity of sorgoleone: a potent PSII inhibitor in Sorghum spp. root exudates. Weed Technol 15:813-825

8. Czarnota MA, Paul RN, Weston LA, Duke SO (2003). Anatomy of sorgoleone-secreting root hairs of Sorghum species. International Journal of Plant Science 164: 861866.

9. Delabays N, Mermillod G, Bohren C (2004). Mauvaises herbes résistantes aux herbicides en Suisse: passé, présent,... futur? Revue suisse Agric. 36:149-154.

10. Ferguson J, Rathinasabapathi B, Chase CA (2013). Allelopathy: How plants suppress other plants. University of Florida IFAS Extension 132-135

11. Friedman T, Horowitz M (1971). Weed Sci.19:398-401.

12. Muntean LS, Borcean I, Axinte M, Roman GhV (2003). Fitotehnie. Ed. Ion Ionescu de la Brad. Iași

13. Nguyen TL, Nguyen CQB, Nguyen TKT, Bui ChB (2010). Sequencing and identification of homologous region encoding rust resistant-gene in soybean (Glycine max L.). Omonrice 17: 65-70

14. Oudhia P, Kolhe SS, Tripathi RS (1999). Germination and seedling vigour of rice var. Mahamaya as affected by allelopathy of Datura stramonium. Crop Res. 18:46-49

15. Putnam AR (1988). Allelochemicals from plants as herbicides. Weed Technol. 2:510-518.

16. Sene M, Gallet C, Dore T (2001). Phenolic compounds in a Sahelian sorghum (Sorghum bicolor) genotipe(ce(145-66)) and associated soils J. Chem. Ecol. V 27 n. 1: 81-92

17. Soufan R, Almouemar A (2009). Allelopathic effects of some weeds on grouth of maize (Zea mays L.). XIII-èmé Colloque International sur la Biologie des Mauvaies Herbes Dijon

18. Ștef R, Bostan C, Butu A, Ortan A, Rodino S, Butu M (2013). Comparative characteristics of Lupinus perenis 
L. under allelochemical sorgoleone stress. Romanian Biotechnological letters, Vol. 18. No. 3.

19. Uludag A, Uremis I, Arslan M, Gozcu D (2005). Jhonsongrass control using Brassicaceae crops. 4th MGPR Sympsosium. 123.
20. Weston LA (2005). History and current trends in the use of allelopathyfor weed management. Proceedings of the 4 th World Congress on Allelopathy.15-21

21. Yang X, Scheffler B, Weston LA (2004). Cloning of SOR 1, a gene associated with bioherbicide production in sorghum root hairs. J. Expt. Bot. 55:2251-2259. 